\title{
WATER DEFICIT ON GERMINATION AND VIGOUR IN SEEDS OF THE JAMBU
}

\section{DÉFICIT HÍDRICO NA GERMINAÇÃO E VIGOR DE SEMENTES DE JAMBU}

\section{Erivanessa Costa Sousa SARMENTO' ${ }^{1}$; Fernando Sarmento de OLIVEIRA ${ }^{2}$; Brenna Rafaella Verissímo dos SANTOS ${ }^{3}$; Salvador Barros TORRES ${ }^{4}$; Clarisse Pereira BENEDITO ${ }^{4}$; Alek Sandro DUTRA ${ }^{5}$}

1. Doutoranda do Programa de Pós-Graduação em Agronomia-Fitotecnia, Universidade Federal do Ceará-UFC, Fortaleza, CE, Brasil. vanessac.sousa@hotmail.com; 2. Doutorando do Programa de Pós- Graduação em Agronomia-Fitotecnia, Universidade Federal Rural do Semi-Árido - UFERSA, Mossoró, RN, Brasil; 3. Mestra em Agronomia- Fitotecnia, Universidade Federal Rural do Semi-Árido UFERSA, Mossoró, RN, Brasil; 4. Professor (a) do Programa de Pós- Graduação em Agronomia-Fitotecnia, Universidade Federal Rural do Semi-Árido - UFERSA, Mossoró, RN, Brasil; 5. Professor do Programa de Pós-Graduação em Agronomia-Fitotecnia, Universidade Federal do Ceará-UFC, Fortaleza, CE, Brasil.

\begin{abstract}
Water availability influences plant metabolism during the various stages of development, especially in the period between germination and seedling emergence. The aim of this study was to evaluate the effect of water deficit during the germination process on seeds of A. oleracea. The experiment was carried out in a completely randomised design, with four replications of 50 seeds. The treatments were arranged in a $5 \times 2$ factorial scheme, with the first factor consisting of the osmotic potentials $(-0.2,-0.4,-0.6$, 0.8 and distilled water for the potential $0.0 \mathrm{MPa}$ ) and the second factor consisting of two lots of seed. The germination test was carried out on substrates moistened with solutions of mannitol and polyethylene glycol (PEG 6000) at the various potentials, in a Biochemical Oxygen Demand (BOD) germinator at a temperature of $30^{\circ} \mathrm{C}$ and under constant light. The test was evaluated daily for 14 days, considering the seeds that had a root length equal to or greater than two millimetres as having germinated. The variables under analysis were germination, germination speed index, seedling length and seedling dry weight. The germination process of $A$. oleracea is compromised at water potentials of $-0.2 \mathrm{MPa}$ and $-0.4 \mathrm{MPa}$ when submitted to PEG and mannitol respectively. Seeds from Lot 1 were more tolerant to the water deficit than were those from Lot 2.
\end{abstract}

KEYWORDS: Acmella oleracea. Unconventional vegetable. Asteraceae. Osmotic potential. PEG 6000. Mannitol.

\section{INTRODUCTION}

Acmella oleracea LRK Jansen, known locally as jambu, is a small, unconventional herbaceous vegetable, native to and widely cultivated in the Amazon region, but of socioeconomic importance for the State of Pará, Brazil, one of the largest producers and consumers of this species (COSTA et al. al., 2013). In this region, $A$. oleracea is widely used in cooking and in folk medicine as an anti-inflammatory, antiseptic and anaesthetic, mainly due to the active principles saponins, alkaloids and flavonoids (ABEYSIRI et al., 2013). Important among these bioactive compounds is spilanthol, which can have a wide variety of biological and pharmacological effects, including analgesic, neuroprotective, antiinflammatory, antimicrobial and insecticidal action (RODRIGUES et al., 2014; BARBOSA et al., 2016).

Cultivation of A. oleracea is preferably carried out under hot and humid conditions, with temperatures over $25^{\circ} \mathrm{C}$, an annual rainfall of 2,761 $\mathrm{mm}$ and relative humidity of around $80 \%$ (Poltronieri et al., 2000), conditions which are typical of the Amazon region. Even so, dry periods can still occur in this region during the rainy season, and consequently the problems caused by water deficit, such as a reduction in germination and seed vigour.

Water is one of the factors that most influences the germination process, since its absorption by seeds results in rehydration of the tissue, and intensifies respiration and all other metabolic activity, culminating in the supply of energy and nutrients necessary for the resumption of growth by the embryonic axis (CARVALHO; NAKAGAWA, 2012). Water absorption at the beginning of imbibition can be hampered by very negative potentials, making the sequence of processes related to germination impossible (BOTELHO, PEREZ, 2001), as when this occurs, it usually results in a reduction in the speed and percentage of seed germination (ÁVILA et al., 2007). 
One of the methods used in the laboratory to simulate a water deficit in the substrate has been the use of aqueous solutions of different osmotic potentials. These include polyethylene glycol (PEG) and mannitol, whose osmotic agents are chemically inert, non-toxic and non-electrolytic (MARCOSFILHO, 2015). Polyethylene glycol is characterised by not penetrating the cells due to its high molecular weight; however, it can cause a delay in the germination process or a reduction in germination (VILLELA et al., 1991). On the other hand, mannitol has a low molecular weight, which may allow its absorption and metabolisation, thereby reducing the water deficit caused by the solute (FANTI; PEREZ, 2004). As a result, seeds submitted to different concentrations of mannitol may present greater tolerance to stress when compared to PEG (PELEGRINI et al., 2013).

In the literature, several vegetable species have been studied in relation to the effects of water deficit on germination and vigour, such as the lettuce (Lactuca sativa) (BERTAGNOLLI et al., 2003), carrot (Daucus carota) (SILVA et al., 2011), cucumber (Cucumis sativus) (MATIAS et al., 2015) and beetroot (Beta vulgaris) (MACIEL et al., 2015). However, for A. oleracea, information on the effects of water deficit on the germination process is nonexistent, which makes it necessary to understand the behaviour of this species when subjected to conditions of water deficit.

Based on the above, the aim of this study was to evaluate the effects of water deficit on the germination process and vigour in seeds of $A$. oleracea.

\section{MATERIAL AND METHODS}

The experiment was carried out in the Seed Analysis Laboratory of the Centre for Agricultural Sciences of the Federal Rural University of the Semi-Arid Region (UFERSA), in Mossoró in the State of Rio Grande do Norte, Brazil, from October to December 2016.

Inflorescences of A. oleracea were collected from spontaneous plants in the districts of Belém (01'27'2" S, 48 30'16" W, altitude $10 \mathrm{~m})$, which comprised Lot 1 , and Castanhal $\left(01^{\circ} 17^{\prime} 38^{\prime \prime} \mathrm{S}\right.$, $47^{\circ} 55^{\prime} 35^{\prime \prime} \mathrm{W}$, altitude $41 \mathrm{~m}$ ), comprising Lot 2 . The inflorescences were left to dry in a shaded, ventilated environment for five days (HOMMA et al., 2011). The seeds were extracted manually and processed by generic air blower to remove the palea. They were then placed in polyethylene bags and stored under controlled conditions $\left(18{ }^{\circ} \mathrm{C}\right.$ and $50 \%$ ambient relative humidity) until the experiment.
Two trials were carried out to simulate water deficit during the germination process. To do this, the seeds were submitted to different osmotic potentials induced by mannitol and polyethylene glycol (PEG 6000), solutions of which were prepared as per the Van't Hoff formula (SIMONI; CHAGAS, 2007) and the table proposed by Villela et al. (1991) respectively.

The trials were conducted in a completely randomised design, with four replications of 50 seeds. The treatments were arranged in a $5 \times 2$ factorial scheme, where the first factor corresponded to the osmotic potentials $(-0.2,-0.4,-0.6,-0.8 \mathrm{MPa}$, and distilled water $-0.0 \mathrm{MPa}$ ) and the second factor consisted of the seed lots (1 and 2).

For monitoring purposes, the water content of the seeds was initially determined by the standard method at $105 \pm 3{ }^{\circ} \mathrm{C}$ for 24 hours, using two $5 \mathrm{~g}$ sub-samples of seeds (BRASIL, 2009). To evaluate the effect of the water deficit on germination and vigour, the following evaluations were carried out: a) Germination test - before setting up the test, asepsis of the A. oleracea seeds was carried out in $1 \%$ sodium hypochlorite for 40 seconds; the seeds were then washed in running water (AIMI et al., 2016). The germination tests were conducted in a Biochemical Oxygen Demand (BOD) germinator at a temperature of $30{ }^{\circ} \mathrm{C}$ and under constant light. Gerbox ${ }^{\circledR}$ transparent acrylic boxes $(11 \times 11 \times 3.5$ $\mathrm{cm})$ were used, the seeds being placed on two sheets of blotting paper, put inside the box and moistened with solutions of PEG 6000, mannitol, and distilled water in an amount equivalent to 2.5 times the weight of the dry paper. To avoid evaporation of the substrate, the boxes were closed and packed into transparent plastic bags, $0.05 \mathrm{~mm}$ thick. Seeds that had a primary root equal to or greater than two millimetres were considered to have germinated (REHMAN et al., 1996). Evaluation took place daily for 14 days with the results expressed as a percentage of germinated seeds. b) Germination speed index - carried out together with the germination test, and evaluated based on the sum of normal seedlings germinated daily divided by the number of days corresponding to the count. The index was calculated from the daily data following the recommendations of Maguire (1962). c) Seedling length - evaluated at the end of the germination test as per the procedure described by Nakagawa (1999). The length of normal seedlings was measured from the primary root to the leaf apex using a rule graduated in millimetres, and the results expressed in $\mathrm{cm}$ seedling ${ }^{-1}$. d) Seedling dry weight normal seedlings were packed into identified Kraft paper bags and placed in a forced air circulation 
oven at $65 \pm 3{ }^{\circ} \mathrm{C}$ for 72 hours. After drying, the seedlings were weighed on an analytical balance $(0.0001 \mathrm{~g})$ and the results expressed in $\mathrm{mg}$ seedling 1 .

The data were submitted to analysis of variance by F-test $(\mathrm{p} \leq 0.05)$. Where the results were significant, the mean values of the qualitative factors (lots) were compared by Tukey's test at 5\% probability and the quantitative factors (osmotic potentials) by regression analysis, using the SISVAR statistical software (FERREIRA, 2011). It was not possible to carry out regression analysis for germination speed index, seedling length or seedling weight, as there were no normal seedlings from a potential of $-0.4 \mathrm{MPa}$ onward. Therefore, to compare the mean values, Tukey's test was applied at $5 \%$ probability.

\section{RESULTS AND DISCUSSION}

The seeds of $A$. oleracea submitted to PEG showed an interaction between lot and the osmotic potential for germination and seedling length, whereas for the germination speed index, an isolated effect was noted from the factors of osmotic potential and lot; there was no significant effect in relation to seedling dry weight (Table 1). When submitted to mannitol, an interaction between lot and osmotic potential was found for germination speed index, seedling length and seedling dry weight; there was an isolated effect from the factors of lot and potential for germination only. The seeds of Lots 1 and 2 had a water content of 7 and $7.4 \%$ respectively.

Table 1. Summary of the variance analysis for germination (G), germination speed index (GSI), seedling length (SL) and seedling dry weight (SDW) in seeds of the jambu (Acmella oleracea LRK Jansen) from two lots from the State of Pará, Brazil, grown under water deficit induced by PEG 6000 and mannitol.

\begin{tabular}{lcccc}
\hline \multirow{2}{*}{ Source of variation } & \multicolumn{4}{c}{ Mean Square } \\
\cline { 2 - 5 } & G & GSI & SL & SDW \\
\hline Lot (L) & $893,02^{* *}$ & $1225,00^{* *}$ & $0,003600^{\text {ns }}$ & $0,015625^{\text {ns }}$ \\
Potentials PEG (PP) & $10094,40^{* *}$ & $2256,25^{* *}$ & $0,354025^{*}$ & $0,390625^{\text {ns }}$ \\
L x PP & $217,52^{* *}$ & $36,00^{\text {ns }}$ & $0,384400^{*}$ & $0,015625^{\text {ns }}$ \\
PEG error & 34,50 & 104,04 & 0,044196 & 4,203125 \\
\hline CV PEG (\%) & 13,57 & 43,17 & 9,56 & 35,08 \\
\hline Lot (L) & $592,90^{* *}$ & $25,60^{* *}$ & $2,111402^{* *}$ & $14,400000^{* *}$ \\
Potentials mannitol (PM) & $195,90^{* *}$ & $183,33^{* *}$ & $6,565829^{* *}$ & $66,287500^{* *}$ \\
L x PM & $57,90^{\text {ns }}$ & $4,66^{* *}$ & $1,148759^{* *}$ & $2,962500^{* *}$ \\
Mannitol error & 33,63 & 0,53 & 0,024674 & 0,350000 \\
\hline CV mannitol (\%) & 7,55 & 15,88 & 11,50 & 17,15 \\
\hline
\end{tabular}

$\mathrm{CV}=$ coefficient of variation; $\mathrm{ns}=$ not significant; $* *, *=$ significant at 1 and $5 \%$ by $\mathrm{F}$ test, respectively.

The seeds of both lots showed a reduction in germination as the osmotic potential decreased. When submitted to PEG (Figure 1A), the seeds of Lot 1 displayed minimum germination at a potential of $-0.6 \mathrm{MPa}(18 \%)$, while for those of Lot 2, minimum germination occurred at $-0.4 \mathrm{MPa}(50 \%)$, with zero germination for both lots at a potential of $0.8 \mathrm{MPa}$. For the mannitol (Figure 1B), the seeds germinated at all osmotic potentials, with the lowest values at a potential of $-0.8 \mathrm{MPa}(68 \%)$, and greater germination at higher potentials. The seeds of Lot 1 displayed higher germination (96\%) compared to those of Lot 2 (90\%) (Figure 1C).

The difference in germination between the two lots may be due to where they were cultivated, harvesting times and environmental conditions, since pre and post-harvest management may have influenced the physiological quality of the seeds (PAIVA et al., 2016).

In general, very negative osmotic potentials increase prolongation of the stationary phase of imbibition (Phase II), characterised by a decrease in the difference in matric force. As the water is absorbed by the seed, the value of the matrix component becomes more negative and the water absorption gradient decreases, causing water to enter the seed more slowly (BEWLEY et al., 2013). Because of this, there is less development of the meristem, root emergence and germination (BRACCINI et al., 1998). 

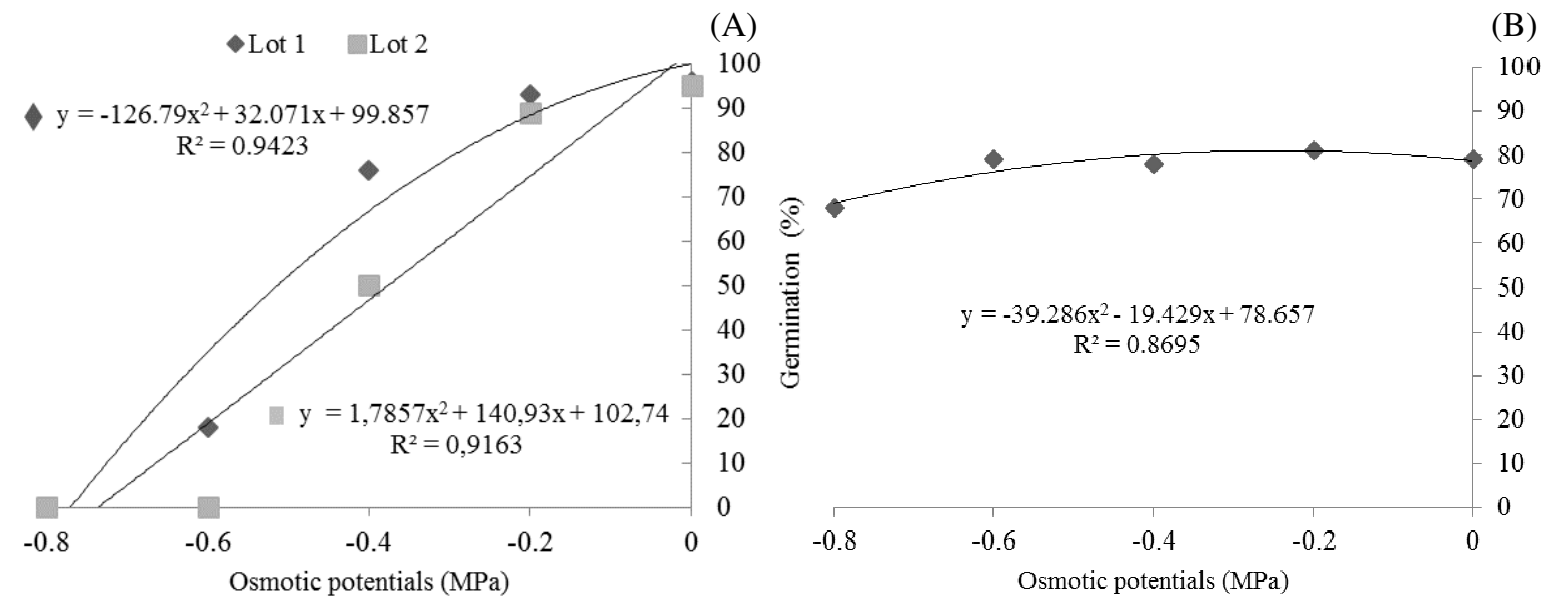

$\frac{8}{8}$

(C)

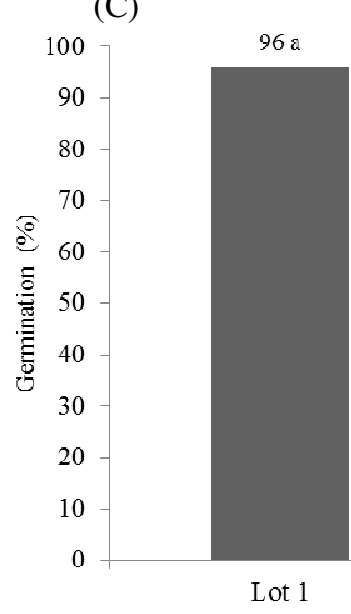

$90 \mathrm{~b}$

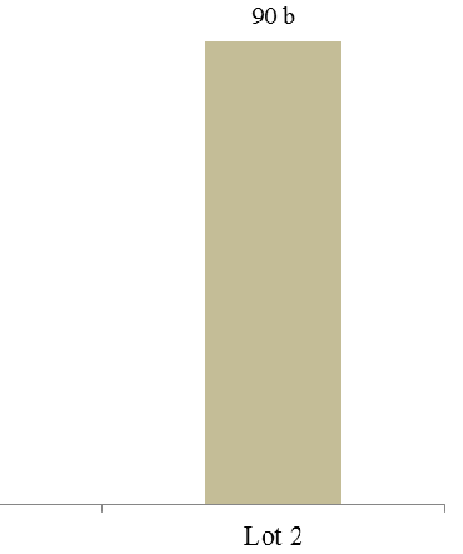

Figure 1. Germination in seeds of the jambu (Acmella oleracea L. R. K. Jansen) from two lots from the State of Pará, Brazil, grown under water deficit induced by PEG 6000 (A) and mannitol (B and C). Mean values followed by the same letter do not differ by Tukey's test at $5 \%$ probability.

The negative effects on seed germination of water stress caused by water deficit and induced by osmotic agents have also been reported by other researchers, such as Ávila et al. (2007), testing mannitol in rapeseed (Brassica napus L.), and Dantas et al. (2011), evaluating PEG in the safflower (Carthamus tinctorius L.). In these studies, the authors found respectively, a reduction in germination when the seeds were submitted to potentials of -1.0 and $-0.8 \mathrm{MPa}$. Similar data were found when simulating osmotic potentials induced by mannitol and PEG on germination in seeds of the beetroot, from a potential of $-0.4 \mathrm{MPa}$ (MACIEL et al., 2015). In another study, Silva et al. (2011) found that carrot seeds had little tolerance to water stress simulated by PEG, with a maximum limit for germination at a potential of $-0.3 \mathrm{MPa}$.

No normal seedlings were identified in either lot at PEG potentials of less than $-0.2 \mathrm{MPa}$ due to germination inhibition. However, when using mannitol, there were normal seedlings from both seed lots up to a potential of $-0.6 \mathrm{MPa}$, but with smaller lengths and less percentage germination than at the other potentials, reaching zero germination at -0.8 MPa. Maciel et al. (2015) found that water deficit induced by solutions of PEG and mannitol at potentials of from $-0.8 \mathrm{MPa}$, did not allow shoot development in beetroot, and noted only protrusion of the primary root.

Higher values for the germination speed index were found in seeds from Lot 1 submitted to PEG (Figure 2A). The control treatment (potential of $0.0 \mathrm{MPa}$ ) gave a higher rate of germination with both PEG and mannitol (Figures 2B, 2C). For the seeds of Lot 1 in mannitol, the lowest germination speed index was found at a potential of $-0.6 \mathrm{MPa}$, whereas for those of Lot 2, it was found at a potential of $-0.4 \mathrm{MPa}$ (Figure 2C). Similar results were found when PEG was used to simulate osmotic potentials below $-0.2 \mathrm{MPa}$ in seeds of the cucumber (MATIAS et al., 2015), safflower (DANTAS et al., 2011), lettuce (BERTAGNOLLI et al., 2003) and 
beetroot (MACIEL et al., 2015). In these studies, the authors found a reduction in germination speed and less seedling development.

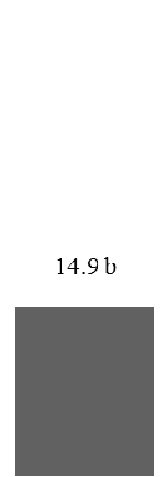

Lot 2

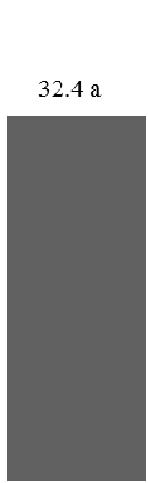

Lot 1

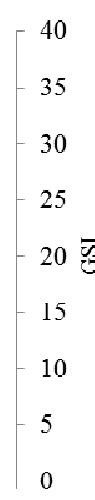

0
(B)

$40+35.5 \mathrm{a} \quad\left[\begin{array}{c}40 \\ \end{array}\right.$

35
-35

$30-30$

$25-25$

20 若

$\begin{array}{ll}15-11.7 \mathrm{~b} & -15\end{array}$

$-10$

$-5$

Osmotic potentials (MPa)

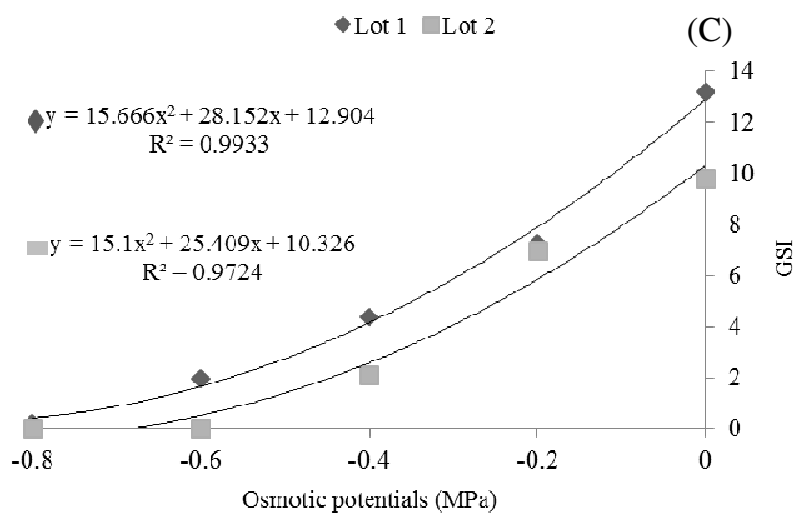

Figure 2. Germination speed index in seeds of the jambu (Acmella oleracea L. R.K. Jansen) from two lots from the State of Pará, Brazil, grown under water deficit induced by PEG 6000 (A, B) and mannitol (C). Mean values followed by the same letter do not differ by Tukey's test at 5\% probability.

The reduction in germination rate as the potential becomes more negative is a result of the interruption of seed tissue rehydration, which consequently promotes less intensification of the respiration and other metabolic activities that culminate in the supply of energy and nutrients necessary for the resumption of growth of the embryonic axis (CARVALHO; NAKAGAWA, 2012).

Water deficit generally decreases the percentage and speed of germination in such a way that the larger the deficit, the longer the germination time (BEWLEY et al., 2013). Negative water potentials reduce imbibition by seeds, thereby preventing the sequence of events related to the germination process (STEFANELLO et al., 2008). As a result, water deficit is one of the main factors that affect seed germination, because in addition to impairing seedling development in the field, it can expose the seeds to unfavourable environmental conditions, as well as to attacks by pests and diseases, causing severe damage (RABBANI et al., 2012).

Seedling length in the PEG treatments (Figure 3A) showed that at a potential $-0.2 \mathrm{MPa}$, Lot 1 showed no changes in relation to the control treatment, on the other hand, Lot 2 had an increase of $24 \%$ in relation to the control treatment. The seedlings from Lot 2 had greater values for length compared to Lot 1 . When the seeds were submitted to mannitol at a potential $-0,2 \mathrm{MPa}$, the seedlings from Lots 1 and 2 displayed respective increases of 4.5 and $3 \%$ relative to the control treatment (Figure 3B). The values decreased in both lots as the potential was reduced from a potential of $-0.2 \mathrm{MPa}$. 

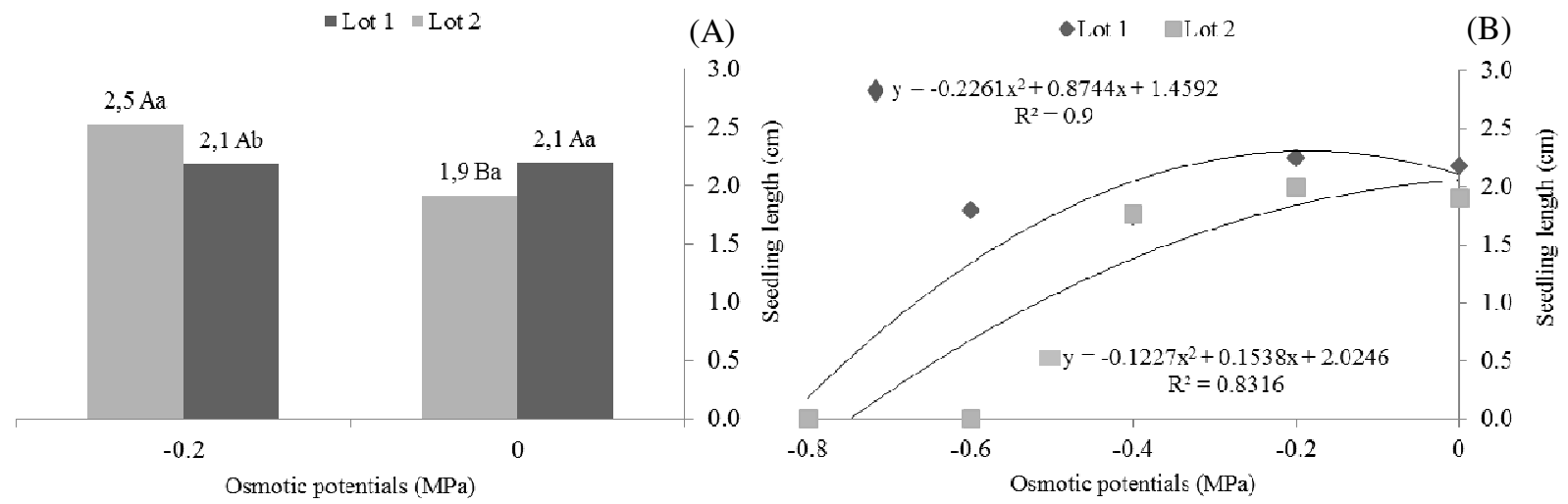

Figure 3. Seedling length in seeds of the jambu (Acmella oleracea L. R.K. Jansen) from two lots from the State of Pará, Brazil, grown under water deficit induced by PEG 6000 (A) and mannitol (B). Mean values followed by the same lowercase letter between lots and uppercase letter between potentials do not differ by Tukey's test at $5 \%$ probability.

Severe water deficit reduces enzyme activity and various physiological and biochemical processes, resulting in reduced meristem development and less-developed seedlings (RABBANI et al., 2012). In addition, Fanti and Perez (2004) emphasise that the first and mostsensitive response to a reduction in the osmotic potential of the imbibition medium is a reduction in cell turgor, and consequently in growth, since cell division, stretching and differentiation are affected during the various physiological stages.

In relation to dry weight (Figure 4), it was found that the seedlings from Lot 1 showed greater accumulation at all potentials compared to those of Lot 2. For both lots, there was reduction in seedling dry weight as the potential decreased, with the lowest values being found in potentials -0.6 and -0.4 MPa for Lot 1 and 2, respectively.

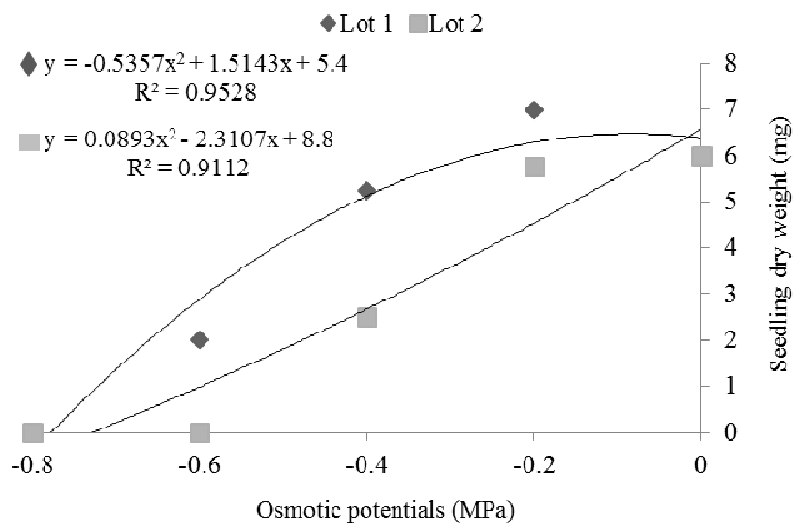

Figure 4. Seedling dry weight in seeds of the jambu (Acmella oleracea L. R.K. Jansen) from two lots from the State of Pará, Brazil, grown under water deficit induced by mannitol.

The reduction in dry weight accumulation may be related to the effect of the water deficit in Phase II of water absorption during seed imbibition (BEWLEY et al., 2013). Further, according to the same authors, in this phase the osmotic potential of the solution is close to that of the embryo, becoming more extensive, and allowing the seeds to activate innumerable events in the germination process with no protrusion of the primary root, thereby delaying the start of Phase III (FERREIRA; BORGHETTI, 2004), reducing seedling development and consequently, the dry-weight content.
Similar results were seen by Ávila et al. (2007), evaluating the effect on rapeseed of water deficit induced by a solution of mannitol. The authors found that a decrease in osmotic potential reduced seedling dry weight from a potential of -0.5 MPa. A reduction also found in Maciel et al. (2015), in seeds of the beetroot submitted to solutions of mannitol and PEG at a potential of -1.4 MPa, when the germination process was inhibited and normal seedlings were not found. 


\section{CONCLUSIONS}

The germination process in seeds of $A$. oleracea is compromised at water potentials below $0.2 \mathrm{MPa}$ and $-0.4 \mathrm{MPa}$ when submitted to PEG and mannitol respectively.
The seeds from Lot 1 proved to be more tolerant to water deficit than those from Lot 2.

\section{ACKNOWLEDGEMENT}

The authors wish to Professor Sérgio Gusmão (UFRA) for donating the A. oleracea seeds.

RESUMO: A disponibilidade de água influencia o metabolismo vegetal nas diversas etapas do desenvolvimento, especialmente no período entre a germinação e a emergência das plântulas. Diante disso, objetivou-se avaliar o efeito do déficit hídrico durante o processo de germinação de sementes de A. oleracea. O experimento foi conduzido em delineamento experimental inteiramente casualizado, com quatro repetições de 50 sementes. Os tratamentos foram arranjados em esquema fatorial 5 x 2, com o primeiro fator constituído pelos potenciais osmóticos $(-0,2 ;-0,4 ;-0,6 ;-0,8$ e água destilada para o potencial $0,0 \mathrm{MPa})$ e o segundo dois lotes de sementes. Para isso, o teste de germinação foi realizado em substratos umedecidos com soluções de manitol e polietilenoglicol (PEG 6000) nos diversos potenciais, em germinador do tipo Biochemical Oxigen Demand (B.O.D.) sob a temperatura de $30{ }^{\circ} \mathrm{C}$ e luz constante. $\mathrm{O}$ teste foi avaliado diariamente durante 14 dias, sendo considerado como germinadas, as sementes que apresentavam extensão radicular igual ou superior a dois milímetros. As variáveis analisadas foram germinação, índice de velocidade de germinação, comprimento de plântulas e massa seca de plântulas. O processo germinativo de sementes de A. oleracea é comprometido a partir de potenciais hídricos de -0,2 MPa e -0,4 MPa, quando submetidas ao PEG e manitol respectivamente. As sementes provenientes do lote 1 mostraram-se mais tolerantes ao déficit hídrico que as do lote 2 .

PALAVRAS-CHAVE: Acmella oleracea. Hortaliça não convencional. Asteraceae. Potencial osmótico. PEG 6000. Manitol.

\section{REFERÊNCIAS}

ABEYSIRI, G. R. P. I.; DHARMADASA, R. M.; ABEYSINGHE, D. C.; SAMARASINGHE, K. Screening of phytochemical, physico-chemical and bioactivity of different parts of Acmella oleraceae Murr. (Asteraceae), a natural remedy for toothache. Industrial Crops And Products, v. 50, p. 852-856, 2013. https://doi.org/10.1016/j.indcrop.2013.08.005

AIMI, S. C.; ARAUJO, M. M.; MUNIZ, M. F. B.; WALKERET, C. Teste de sanidade e germinação em sementes de Cabralea canjerana (Vell.) Mart. Ciência Florestal, Santa Maria, v. 26, n. 4, p. 1361-1370, 2016. http://dx.doi.org/10.5902/1980509825155

ÁVILA, M. R.; BRACCINI, A. L.; SCAPIM, C. A.; FAGLIARI, J. R.; SANTOS, J. L. Influência do estresse hídrico simulado com manitol na germinação de sementes e crescimento de plântulas de canola. Revista Brasileira de Sementes, Londrina, v. 29, n. 1, p. 98-106, 2007. http://dx.doi.org/10.1590/S010131222007000100014

BARBOSA, A. F.; CARVALHO, M. G.; SMITH, R. E.; SABAA-SRUR, A. U. O. Spilanthol: occurrence, extraction, chemistry and biological activities. Revista Brasileira de Farmacognosia, Curitiba, v. 26, n. 1, p. 128-133, 2016. http://dx.doi.org/10.1016/j.bjp.2015.07.024

BERTAGNOLLI, C. M.; MENEZES, N. L.; STORCK, L.; SANTOS, O. S.; PASQUALLI, L. L. Desempenho de sementes nuas e peletizadas de alface (Lactuca sativa L.) Submetidas a estresses hídrico e térmico. Revista Brasileira de Sementes, Londrina, v. 25, n. 1, p. 7-13, 2003. http://dx.doi.org/10.1590/S010131222003000100002

BEWLEY, J. D.; BRADFORD, K.; HILHORST, H.; NONOGAKI, H. Seeds: physiology of development, germination and dormancy. 3. ed. Nova York: Springer, 2013. 392p. 
BOTELHO, B. A.; PEREZ, S. C. J. G. A. Estresse hídrico e reguladores de crescimento na germinação de sementes de canafístula. Scientia Agricola, Piracicaba, v. 58, n. 1, p. 43-49, 2001.

http://dx.doi.org/10.1590/S0103-90162001000100008

BRACCINI, A. L.; REIS, M. S.; SEDIYAMA, C. S.; SEDIYAMA, T.; ROCHA, V. S. Influência do potencial hídrico induzido por polietilenoglicol na qualidade fisiológica de sementes de soja. Pesquisa Agropecuária Brasileira, Brasilia. v. 33, n. 9, p. 1451-1459, 1998. Disponível em:< https://seer.sct.embrapa.br/index.php/pab/article/view/4980>. Acesso em: 07 abr. 2018.

BRASIL. Ministério da Agricultura, Pecuária e Abastecimento. Regras para análise de sementes. Ministério da Agricultura, Pecuária e Abastecimento. Secretaria de Defesa Agropecuária. Brasília: Mapa/ACS, 2009. 399 p.

CARVALHO, N. M.; NAKAGAWA, J. Sementes: ciência, tecnologia e produção. 5.ed. Jaboticabal: FUNEP, 2012. $590 \mathrm{p}$.

COSTA, S. S; ARUMUGAMB, D.; GARIEPYB, Y.; ROCHA, S. C. S.; RAGHAVAN, V. Spilanthol extraction using microwave: calibration curve for gas chromatography. Chemical Engineering Transactions, Milão, v. 32, n.32, p. 1783-1788, 2013.

DANTAS, C. V. S.; SILVA, I. B.; PEREIRA, G. M.; MAIA, J. M.; LIMA, J. P. M. S.; MACEDO, C. E. C. Influência da sanidade e déficit hídrico na germinação de sementes de Carthamus tinctorius L. Revista Brasileira de Sementes, Londrina, v. 33, n. 3, p. 574-582, 2011. http://dx.doi.org/10.1590/S010131222011000300020

FANTI, S. C.; PEREZ, S. C. J. G. A. Processo germinativo de sementes de paineira sob estresses hídrico e salino. Pesquisa Agropecuária Brasileira, Brasília, v. 39, n. 9, p. 903-909, 2004.

http://dx.doi.org/10.1590/S0100-204X2004000900010

FERREIRA, A. G.; BORGHETTI, F. Germinação: do básico ao aplicado. Porto Alegre: Artmed, 2004. 323 p.

FERREIRA, D. F. Sisvar: a computer statistic analysis system. Ciência e Agrotecnologia, Lavras, v. 35, n. 6 , p. 1039-1042, 2011. http://dx.doi.org/10.1590/S1413-70542011000600001

HOMMA, A. K. O.; SANCHES, R. S.; MENEZES, A. J. E. A.; GUSMÃO, S. A. L. Etnocultivo do jambu para abastecimento da cidade de Lote 1, estado do Pará. Amazônia: Ciência \& Desenvolvimento, Belém, v. 6, n. 12, p. 125-141, 2011. Disponível em:<https://ainfo.cnptia.embrapa.br/digital/bitstream/item/56524/1/n12etnocultivo-do-jambu-p.pdf>. Acesso em: 03 out. 2017.

MACIEL, K. S.; LOPES, J. C.; MORAES, C. E.; FARIAS, C. C. M.; LIMA, P. A. M. Germinação de sementes de beterraba em condições de estresse hídrico e salino. Nucleus, Ituperava, v. 12, n. 2, p. 189-199, 2015. http://dx.doi.org/10.3738/1982.2278.1167

MAGUIRE, J. Speed of germination-aid in selection and avaluation for seedling emergence and vigor. Crop Science, Madison, v. 2, n. 1, p. 176-177, 1962. Disponível em:< https://dl.sciencesocieties.org/publications/cs/abstracts/2/2/CS0020020176>. Acesso em: 04 out. 2017.

MARCOS FILHO, J. Fisiologia de sementes de plantas cultivadas. Londrina: ABRATES, 2015. 660 p.

MATIAS, J. R.; SILVA, T. C. F. S.; OLIVEIRA, G. M.; ARAGÃO, C. A.; DANTAS, B. F. Germinação de sementes de pepino cv. Caipira em condições de estresse hídrico e salino. Revista Sodebras, São Paulo, v. 10, n. 113, p. 33-39, 2015. Disponível em:< https://www.researchgate.net/publication/276202846_GERMINACAO_DE_SEMENTES_DE_PEPINO_CV_ CAIPIRA_EM_CONDICOES_DE_ESTRESSE_HIDRICO_E_SALINO>. Acesso em: 10 out. 2017. 
NAKAGAWA, J. Testes de vigor baseados no desempenho das plântulas. In: KRZYZANOWSKI, F. C.; VIEIRA, R. D.; FANÇA NETO, J. B. (Ed.). Vigor de sementes: conceitos e testes. Londrina: ABRATES, 1999. p. 1-24.

PAIVA, C. T. C.; SILVA, J. B.; DAPONT, E. C.; ALVES, C. Z.; CARVALHO, M. A. C. Qualidade fisiológica e sanitária de sementes comerciais de alface e repolho. Revista de Ciências Agroambientais, Alta Floresta, v. 14, n. 1, p. 53-59, 2016. Disponível em:< https://periodicos.unemat.br/index.php/rcaa/article/view/1410>. Acesso em: 07 abr. 2018.

PELEGRINI, L. L.; BORCIONI, E.; NOGUEIRA, A. C.; KOEHLER, H. S.; QUOIRIN, M. G. G. Efeito do estresse hídrico simulado com NaCl, manitol e PEG (6000) na germinação de sementes de Erythrina falcata Benth. Ciência Florestal, Santa Maria, v. 23, n. 2, p. 511-519, 2013. http://dx.doi.org/10.5902/198050989295

POLTRONIERI, M. C .; MÜLLE, N. R. M.; POLTRONIERI, L. S. Recomendações para a produção de jambu: cultivar nazaré. Belém: Embrapa Amazônia Oriental, 2000. 13p. (Embrapa Amazônia Oriental. Circular Técnica, 11).

RABBANI, A. R. C.; MANN, R. S.; FERREIRA, R. A.; PESSOA, A. M. S.; BARROS, E. S.; MESQUITA, J. B. Restrição hídrica em sementes de moringa (Moringa oleifera L.). Revista Científica UDO Agrícola, Cumaná, v. 12, n. 3, p. 563-569, 2012. Disponível em:<

https://www.google.com.br/search?q=Restri\%C3\%A7\%C3\%A3o+h\%C3\%ADdrica+em+sementes+de+moring $\mathrm{a}+($ Moringa+oleifera+L.).\&oq=Restri $\% \mathrm{C} 3 \% \mathrm{~A} 7 \% \mathrm{C} 3 \% \mathrm{~A} 3 \mathrm{o}+\mathrm{h} \% \mathrm{C} 3 \%$ ADdrica+em+sementes+de+moringa+(Mo ringa+oleifera+L.).\&aqs=chrome..69i57.1485216j0j9\&sourceid=chrome\&ie=UTF-8>. Acesso em: 13 out. 2017.

REHMAN, S.; HARRIS, P. J. C.; BOURNE, W. F.; WILKIN, J. The effect of sodium chloride on germination and the potassium and calcium contents of Acacia seeds. Seed Science and Technology, Zurich, v. 25, n. 1, p. 45-57, 1996. Disponível em:< https://www.researchgate.net/publication/236856416_The_Effect_of_Sodium_Chloride_on_Germination_and_ the_Potassium_and_Calcium_Contents_of_Acacia_Seeds>. Acesso em: 13 out. 2017.

RODRIGUES, D. S.; CAMARGO, M. S.; NOMURA, E. S.; GARCIA, V. A.; CORREA, J. N.; VIDAL, T. C. M. Influência da adubação com nitrogênio e fósforo na produção de jambu, Acmella oleracea (L) R. K. Jansen. Revista Brasileira de Plantas Medicinais, Campinas, v. 16, n. 1, p. 71-76, 2014. http://dx.doi.org/10.1590/S1516-05722014000100010

SILVA, M. C. C.; MEDEIROS, A. F. A.; DIAS, D. C. F. S.; ALVARENGA, E. M.; COELHO, F. S.; BRAUN, $\mathrm{H}$. Efeito do estresse hídrico e térmico na germinação e no vigor de sementes de cenoura. IDESIA, Arica, v. 29, n. 3, p. 39-44, 2011. http://dx.doi.org/10.4067/S0718-34292011000300006

SIMONI, J. A.; CHAGAS, A. P. Diagramas de ellingham e de Van't Hoff: algumas considerações. Química Nova, São Paulo, v. 30, n. 2, p. 501-504, 2007. http://dx.doi.org/10.1590/S0100-40422007000200047

STEFANELLO, R.; GARCIA, D. C.; MENEZES, N. L.; CASTILHOS, G. Efeito do estresse hídrico na germinação e no vigor de sementes de anis (Pimpinella anisum L.), funcho (Foeniculum vulgare Miller) e endro (Anethum graveolens L.) Revista Brasileira de Plantas Medicinais, Botucatu, v. 10, n. 2, p. 68-74, 2008. Disponível em:< http://www.ibb.unesp.br/Home/Departamentos/Botanica/RBPMRevistaBrasileiradePlantasMedicinais/artigo11_v10n2.pdf>. Acesso em: 13 out. 2017.

VILLELA, F. A.; DONI-FILHO, L.; SEQUEIRA, E. L. Tabela de potencial osmótico em função da concentração de polietileno glicol 6000 e da temperatura. Pesquisa Agropecuária Brasileira, Brasília, v. 26, n. 11/12, p. 1957-1968, 1991. Disponível em:< https://seer.sct.embrapa.br/index.php/pab/article/view/3549>. Acesso em: 13 out. 2017. 